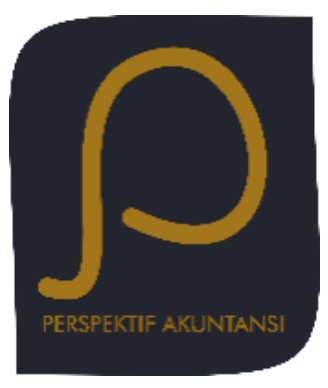

Perspektif Akuntansi

Volume 4 Nomor 3 (Oktober 2021), hal. 239-254

ISSN: 2623-0194 (Print), 2623-0186 (Online)

Copyright(C The Authors(s). All Rights Reserved

Center for Accounting Development and Research (CARD)

Fakultas Ekonomika dan Bisnis,

Universitas Kristen Satya Wacana

DOI: https://doi.org/10.24246/persi.vXiX.p239-254

http://ejournal.uksw.edu/persi

\title{
Efek Budaya Negara Terhadap Agresivitas Pajak dengan Moderasi Persepsi Atas Korupsi: Pendekatan Multicountry
}

\author{
Bagas Aldhian ${ }^{1}$ \\ Kantor Akuntan Publik Leonard, Mulia, dan Richard \\ Theresia Woro Damayanti \\ Universitas Kristen Satya Wacana
}

\begin{abstract}
Received
08/04/2021

Revised

05/07/2021

Accepted

06/07/2021

Abstract. National culture in each country needs to be considered because it can be one of the factors of tax aggressiveness. In this study several dimensions including distance of power, individualism, uncertainty and masculinity of a person can carry out acts of tax aggressiveness.. However, the distance of power, individualism, uncertainty and masculinity can change when there is corruption in the country. The purpose of this study is to look at the influence of power distance, individualism, uncertainty, and masculinity by adding moderation variables, namely corruption against someone to carry out acts of tax aggressiveness.. In this study the data used are secondary data, obtained from the World Bank's Enterprise Survey (WBES) in 2006 to 2018. In analyzing these data using Multinomial Logistic Regression (MLR). This sudy confirmed that masculinity effect tax aggressiveness but power distance, individualism, uncertainty not effected on tax aggressiveness. Moreover, corruption has influence the relationship between masculinity and tax aggressiveness.
\end{abstract}

Keywords: Power Distance, Individualism, Uncertainty, Masculinity, Tax aggressiveness

\footnotetext{
1Bagasaldhian@2806@gmail.com
} 


\begin{abstract}
Abstrak. Budaya nasional dalam setiap negara perlu diperhatikan karena dapat menjadi salah satu faktor agresivitas pajak. Dalam penelitian ini beberapa dimensi diantaranya jarak kekuasaan, individualisme, ketidakpastian dan maskulinitas seseorang bisa saja melakukan tindakan agresivitas pajak. Akan tetapi jarak kekuasaan, individualisme, ketidakpastian dan maskulinitas dapat berubah ketika ada korupsi di suatu negara tersebut. Tujuan dari penelitian ini adalah untuk melihat pengaruh jarak kekuasaan, individualisme, ketidakpastian, dan maskulinitas dengan menambahkan variabel moderasi yaitu korupsi terhadap seseorang untuk melakukan tindakan agresivitas pajak. Dalam penelitian ini data yang digunakan adalah data sekunder, yang diperoleh dari World Bank Enterprise Survey (WBES) pada tahun 2006 sampai dengan tahun 2018. Dalam menganalisis data tersebut menggunakan Multinomial Logistic Regression (MLR). Hasil studi ini menunjukkan bahwa maskulinitas berpengaruh terhadap agresivitas pajak namun jarak kekuasaan, individualisme dan ketidakpastian tidak berpengaruh terhadap agresivitas pajak. Selain itu hasil studi ini menunjukkan bahwa korupsi memoderasi pengaruh antara maskulinitas dengan agresivitas pajak.
\end{abstract}

Kata kunci: Jarak Kekuasaan, Individualisme, Ketidakpastian, Maskulinitas, Agresivitas pajak

\title{
Pendahuluan
}

Agresivitas pajak (tax aggressiveness) menjadi persoalan yang penting di banyak negara dalam jangka waktu yang lama. Agresivitas pajak menurut Rahayu (2010) adalah sebuah cara atau usaha yang dilakukan oleh seorang wajib pajak dalam memanipulasi, menyembunyikan, dan bahkan menghapuskan secara ilegal terhadap utang pajak atau menghindari diri untuk tidak membayarkan pajak sebagaimana yang telah terutang menurut perundang-undangan perpajakan yang seharusnya dibayarkan. Agresivitas pajak pada umumnya tentu melibatkan kegiatan ekonomi yang sengaja disembunyikan (Bame-Aldred et al., 2013). IRS (2007) melaporkan bahwa beberapa negara telah melakukan kegiatan transaksi ekonomi yang tidak sesuai dengan peraturan yang ada, sehingga mengalami ekonomi tersembunyi antara 6\% dari PDB (Swiss) dan 27\% dari PDB (Italia) (Giles, 1998). Setiap negara maju, ataupun negara berkembang, membutuhkan penerimaan pajak untuk investasi negara tersebut dalam layanan sosial maupun infrastruktur ekonomi. Dengan demikian, agresivitas pajak penghasilan, baik itu pribadi ataupun bisnis, berpotensi merugikan masyarakat kalangan menengah kebawah (Asmoro, 2016).

Studi tentang agresivitas pajak antar negara mempertimbangkan berbagai faktor termasuk kelembagaan misalnya tarif pajak perusahaan (Nielsen et al., 2010), keadilan pajak (Brock \& Pogge, 2014), serta pendapatan rendah atau tinggi dan juga secara demografi (Bame-Aldred et al., 2013) misalnya ukuran perusahaan dan 
kepemilikan perusahaan (Richardson, 2006). Long, Swingen, Roth, Scholz, \& Witte (1991) dalam penelitiannya menyebutkan bahwa saat ini banyak perusahaan yang melakukan agresivitas pajak tersebut, agresivitas pajak salah satunya terjadi karena adanya faktor budaya negara, bermacam budaya yang membentuk sebuah kelompok dan kejadian peristiwa yang dapat mempengaruhi sikap masyarakat terhadap agresivitas pajak. Meskipun beberapa penelitian lainnya telah mempertimbangkan bagaimana budaya negara berhubungan dengan agresivitas pajak (Richardson, 2006; Tsakumis, Curatola, \& Porcano, 2007; Bame-Aldred et al., 2013), namun budaya nasional saja tidak cukup untuk menjelaskan agresivitas pajak. Tingkat korupsi dalam sebuah negara juga menjadi hal yang dipertimbangkan ketika wajib pajak melakukan agresivitas pajak. Adanya kasus korupsi yang dilakukan oleh petugas pajak menjadi pemicu masyarakat untuk tidak patuh membayarkan dan melaporkan pajaknya (Christianto \& Suyanto, 2014). Selain itu menurut Fochmann dan Kroll (2016) kejelasan distribusi pajak berpengaruh terhadap wajib pajak. Maka jika hal tersebut terjadi dan bahkan banyak terjadi dilakukan, maka hal tersebut akan mengurangi tingkat kepatuhan seseorang wajib pajak dalam membayarkan kewajiban perpajakannya.

Studi ini melengkapi studi sebelumnya yang hanya melihat dari sisi budaya dengan menambahkan variabel moderasi yaitu korupsi yang dapat diukur melalui indeks persepsi korupsi atau corruption perception index. Dengan demikian, studi ini bertujuan untuk melihat pengaruh jarak kekuasaan, individualisme, ketidakpastian, dan maskulinitas terhadap agresivitas pajak dan menambahkan variabel moderasi yaitu persepsi atas korupsi. Manfaat dari penelitian ini yaitu diharapkan dapat memberikan pandangan mengenai pemahaman faktor-faktor yang mempengaruhi agresivitas pajak.

\section{Telaah Pustaka}

Hofstede (2001) mendefinisikan budaya (culture) sebagai pemrograman kolektif pikiran yang membedakan anggota dari suatu kelompok atau kategori orang dari yang lain. Selain itu budaya nasional adalah pola nilai, kepercayaan dan praktik berbagi antara anggota di sebuah organisasi dapat mempengaruhi pemikiran dan perilaku. Budaya dapat dilihat dari ketentuan satu hal dan bagaimana suatu pemikiran yang didasarkan melalui kepercayaan mereka, tradisi, adat, norma dan bahkan agama. Dalam pernyataan tersebut dapat dipahami bahwa budaya merupakan keseluruhan pola pemikiran, perasaan dan tindakan dari suatu kelompok sosial, yang membedakan dengan kelompok sosial yang lain. Budaya Nasional dikelompokkan ke dalam berbagai tingkatan antara lain: nasional, daerah, gender, generasi, kelas sosial, organisasi atau perusahaan. Hofstede (2001) menyebutkan bahwa budaya nasional memiliki beberapa dimensi diantaranya yaitu jarak kekuasaan, kolektivism dan individualism, maskulinitas dan feminin serta ketidakpastian. 
Dimensi jarak kekuasaan berhubungan dengan suatu keadaan bahwa secara signifikan semua individu dalam masyarakat memiliki tingkatan yang menyebabkan ketidaksetaraan. Hofstede (1980) mengungkapkan sikap budaya terhadap ketidaksetaraan diantara kita. Jarak kekuasaan didefinisikan sebagai sejauh mana anggota lembaga dalam suatu perusahaan ataupun organisasi yang kurang kuat dalam suatu negara mengharapkan dan menerima bahwa kekuasaan dapat didistribusikan secara tidak merata. Sementara, dalam dimensi kolektivis dan individualisme memandang manusia pada intinya adalah makhluk hidup yang sosial, berarti tidak dapat hidup sendiri dalam menjalankan hal apapun. Dalam dimensi ini, Hofstede (1980) menemukan kehidupan manusia yang hidup secara individualis dan kolektivis. Perbedaan dalam dimensi ini berkaitan dengan bagaimana suatu negara berinteraksi dengan negara lain yang membentuk suatu kelompok dengan tujuan tertentu yang disebut sebagai kolektivitas. Sedangkan beberapa orang didunia hidup dalam masyarakat di mana minat-minat untuk hidup tanpa bantuan orang lain dan tidak menyukai hidup bersosialisasi, maka masyarakat tersebut disebut sebagai masyarakat yang individualisme.

Dalam kelompok makhluk hidup manusia terdiri dari laki-laki dan perempuan, secara biologis perbedaan tersebut menggunakan terminologi male dan female. Sedangkan perbedaan sosial dan budaya ditentukan oleh maskulinitas dan feminim. Hofstede (1980) menyebutkan bahwa skor tinggi (maskulin) pada dimensi ini menunjukkan bahwa masyarakat akan didorong oleh kompetisi, prestasi dan kesuksesan, dengan kesuksesan yang ditentukan oleh pemenang terbaik di bidang tertentu. Sedangkan skor rendah (feminim) pada dimensi ini berarti bahwa nilai-nilai dominan dalam kualitas hidup masyarakat. Dimensi yang terakhir yaitu ketidakpastian berhubungan dengan cara suatu masyarakat menghadapi kenyataan bahwa masa depan tidak akan pernah diketahui, namun masa yang akan datang tidak dapat diketahui dengan pasti tetapi harus tetap dihadapi dan dijalani dalam kehidupan tersebut.

\section{Pengaruh Jarak Kekuasaan terhadap Agresivitas Pajak}

Dimensi jarak kekuasaan berfokus pada tingkat kesetaraan atau ketidaksetaraan antara orang-orang di suatu negara. Peringkat jarak kekuasaan yang tinggi menunjukkan bahwa ketidaksetaraan kekuasaan dan kekayaan telah diizinkan untuk tumbuh di dalam negeri. Negara ini umumnya mengikuti sistem kelas yang tidak memungkinkan mobilitas ke atas yang signifikan dari warganya. Peringkat jarak daya yang rendah menunjukkan negara tidak menekankan perbedaan antara kekuatan dan kekayaan warga.

Jarak kekuasaan menekankan posisi jabatan dalam suatu lembaga, organisasi, atau negara Hofstede (1980). Perhatian utama adalah bagaimana masyarakat dalam hal mengatasi ketidaksetaraan posisi jabatan ini. Di negara yang memiliki jarak kekuatan tinggi, Hofstede (2011) menjelaskan bahwa terdapat perbedaan upah di negaranegara dengan jarak daya tinggi juga cukup besar sehingga ada kesenjangan pendapatan antara kelas atas dan kelas bawah. Perbedaan pendapatan yang tinggi ini meningkat karena sistem perpajakan yang berpotensi meningkatkan agresivitas 
pajak. Sistem pajak di negara-negara tersebut cenderung tidak sesuai dan melindungi orang kaya sehingga perbedaan pendapatan yang besar di negara-negara tersebut semakin meningkat oleh sistem pajak (Hofstede, 1980). Dalam lingkungan ini, orang cenderung menganggap sistem pajak tidak adil dan berusaha untuk menghindari pajak penghasilan (Richardson, 2008). Tsakumis et al. (2007) menemukan bahwa jarak kekuasaan yang lebih tinggi berpengaruh pada agresivitas pajak yang lebih tinggi. Dari dimensi jarak kekuasaan dapat disimpulkan adanya pengaruh jarak kekuasaan terhadap wajib pajak melakukan tindakan agresivitas pajak.

$\boldsymbol{H}_{1}$ : Jarak kekuasaan berpengaruh positif terhadap tingkat agresivitas pajak

\section{Pengaruh Individualisme terhadap Agresivitas Pajak}

Dimensi ini berfokus pada sejauh mana suatu negara mendukung suatu pencapaian individu ataupun secara kolektif dan hubungan interpersonal. Peringkat individualisme yang tinggi menunjukkan bahwa individualitas dan hak-hak individu dominan di dalam negeri. Penduduk suatu negara dengan individualisme tinggi, maka negara tersebut cenderung lebih memilih untuk menjalankan segala sesuatu dengan kehendaknya sendiri tanpa meminta hubungan dari negara lain.

Dimensi budaya individualisme ini berhubungan dengan konsep diri seseorang tentang bagaimana dengan diri sendiri ataupun mereka. Hal yang membedakan keduanya adalah tingkat ketergantungan sosial terhadap masyarakat lainnya. Suatu masyarakat dengan persepsi individualisme yang tinggi akan memandang individu sebagai jati diri yang unik, praktis, atau mandiri yang bebas dari sekelompok orang. Di sisi individualis, ikatan antara individu lebih bebas karena semua orang hanya peduli pada keluarga dan keluarga dekat mereka (Hofstede, 2011).

Dengan sistem pajak, penerimaan pajak dari negara yang individual ini akan semakin tinggi. Dari dimensi individualisme ini dapat disimpulkan bahwa tidak adanya pengaruh individualisme terhadap wajib pajak untuk melakukan tindakan agresivitas pajak. Berdasarkan hal tersebut maka hipotesis dalam penelitian ini adalah:

$\boldsymbol{H}_{2}$ : Individualisme berpengaruh negatif terhadap tingkat agresivitas pajak.

\section{Pengaruh ketidakpastian terhadap agresivitas pajak}

Ketidakpastian memberikan ukuran sejauh mana anggota suatu budaya merasa terancam oleh ambiguitas atau situasi yang tidak diketahui, sebagaimana kegelisahan mereka. Dinegara yang lemah ketidakpastian, level kegelisahan relative kecil, agresi dan emosi tidak dimaksudkan untuk ditunjukkan di komunitas yang lemah ketidakpastiannya (Hofstede, 2011). Di negara-negara dengan ketidakpastian yang tinggi, dikarenakan kurangnya kepercayaan pada pemerintah yang mendorong untuk agresivitas pajak sebagai cara meminimalkan kemungkinan akan menyalahgunakan dana. Sedangkan di negara-negara yang ketidakpastiannya rendah, individu lebih dapat dipercaya tentang bagaimana pendapatan pajak mereka akan digunakan oleh pemerintah yang menyebabkan alasan untuk menghindari pajak tersebut. 
Richardson (2008) dalam penelitiannya menguji hubungan antara budaya dan agresivitas pajak di 47 negara terpilih, hasil dari penelitiannya menunjukkan bahwa pada tingkat penghindaran ketidakpastian yang lebih tinggi, tingkat agresivitas pajak lebih tinggi di berbagai negara.

Dari dimensi ketidakpastian ini disimpulkan bahwa adanya pengaruh ketidakpastian terhadap seorang wajib pajak untuk melakukan tindakan agresivitas pajak. Berdasarkan uraian tersebut maka hipotesis yang terjadi adalah:

$\boldsymbol{H}_{3}$ : Ketidakpastian berpengaruh positif terhadap agresivitas pajak

\section{Pengaruh maskulinitas terhadap agresivitas pajak}

Maskulinitas berkaitan dengan peran perbedaan peran antara perempuan dan lakilaki, yang menekankan nilai-nilai (kinerja, pencapaian yang terlihat, hubungan, kepedulian, dan pengasuhan). Dalam dimensi maskulinitas ini dibatasi oleh maskulinitas dan feminitas. Dimensi ini diberi nama tersebut karena satu-satunya dalam penelitian asli dimana pria dan wanita secara konsisten memiliki skor yang berbeda. Perbedaan yang dimaksudkan adalah bersifat sosial dan bahkan lebih ke arah emosional Hofstede (2011). Tsakumis \& Doupnik (2004) menunjukkan masyarakat maskulin memiliki keinginan bahwa kesuksesannya dapat dilihat seluruh masyarakat sehingga mereka mengungkapkan informasi keuangan kepada pihak luar.

Dapat disimpulkan bahwa negara yang memiliki tingkat maskulin yang tinggi, masyarakatnya cenderung berjuang untuk pencapaian tertentu agar dapat meningkatkan ego, kekayaan, dan kesejahteraan, sedangkan masyarakat yang memiliki tingkat maskulinitas yang rendah, masyarakatnya berusaha keras untuk mencapai prestasi dalam kualitas sosial dengan yang lain. Namun hal ini didukung oleh Hofstede (2001), yang menemukan korelasi negatif yang signifikan antara maskulinitas dengan pandangan nasional.

$\boldsymbol{H}_{4}$ : Maskulinitas berpengaruh positif terhadap agresivitas pajak.

\section{Pengaruh Budaya Nasional terhadap Agresivitas Pajak dengan Persepsi Korupsi sebagai Pemoderasi.}

Penelitian Khlif dan Amara (2017) menyebutkan bahwa lingkungan persepsi korupsi yang tinggi cenderung akan memberikan dampak untuk melakukan kejahatan keuangan yang menyiratkan kepatuhan pajak yang rendah. Persepsi korupsi juga dapat mengurangi kemampuan negara manapun untuk menegakkan hukum dan menghukum seseorang yang melakukan kejahatan tersebut dan dengan demikian agresivitas pajak lebih tinggi terjadi.

Persepsi korupsi didefinisikan sebagai penggunaan kekuasaan publik untuk mendapatkan keuntungan pribadi (Picur \& Riahi-Belkaoui, 2006). Korupsi melibatkan operasi dimana orang membayar dengan sejumlah uang atau 
memberikan layanan sebagai imbalan terlarang oleh public (Andreoni et al., 1998). Tingkat persepsi korupsi yang tinggi di suatu negara, memungkinkan akan mengurangi kecenderungan individu untuk menerima dan mempercayai pemerintah secara umum dan mematuhi beban pajak pada khususnya. Dengan demikian peneliti mencoba mengeksplorasi bagaimana tingkat persepsi korupsi dapat memoderasi pengaruh antara tingkat budaya nasional dan agresivitas pajak tersebut dan mengambil data melalui Indeks Persepsi Korupsi (IPK)/Corruption Perception Index (CPI),

$\boldsymbol{H}_{5} \boldsymbol{a}$ : Persepsi korupsi memoderasi individualisme terhadap agresivitas pajak.

$\boldsymbol{H}_{5} \boldsymbol{b}$ : Persepsi korupsi memoderasi jarak kekuasaan terhadap agresivitas pajak.

$\boldsymbol{H}_{5} \boldsymbol{C}$ : Persepsi korupsi memoderasi ketidakpastian terhadap agresivitas pajak.

$\boldsymbol{H}_{5} \boldsymbol{d}$ : Persepsi korupsi memoderasi maskulinitas terhadap agresivitas pajak.

\section{Metoda}

Studi ini menguji prediksi tentang agresivitas pajak dan budaya menggunakan data sekunder dari World Bank, yang dikumpulkan dari berbagai perusahaan swasta yang berlokasi di negara-negara di seluruh dunia. Dalam penelitian World Bank mengidentifikasi dengan cara wawancara secara langsung kepada responden. Responden mewakili perusahaan dari berbagai ukuran dan usia perusahaan tersebut. World Bank pada tahun 2019 di 142 negara terhadap 136.887 perusahaan, karena studi ini meneliti tentang pajak maka yang digunakan hanya perusahaan yang formal dengan total 44.527 perusahaan

Dalam studi ini, jenis data yang digunakan yaitu data sekunder dengan model penelitiannya yaitu quantitative research. Data tersebut didapatkan melalui World Bank pada tahun 2006-2018. Variabel budaya nasional yang menjadi variabel independen dalam studi ini didefinisikan sebagai pola nilai, kepercayaan dan praktik berbagi antara anggota di sebuah organisasi dapat mempengaruhi pemikiran dan perilaku. Budaya dapat dilihat dari ketentuan satu hal dan bagaimana suatu pemikiran yang didasarkan melalui kepercayaan mereka, tradisi, adat, norma dan bahkan agama (Hofstede, 1980). Indikator yang digunakan untuk mengukur variabel budaya nasional adalah data persentase yang terdapat dalam website Jarak Kekuasaan, Individualisme, ketidakpastian dan Maskulinitas. Jika jarak kekuasaan 050 (small), 50-100 (large); Ketidakpastian 5-60 (weak), 60-115 (Strong); Individualisme 5-50 (Collectivism), 50-95 (Individualism); Maskulinitas 5-50 (Feminism), 50-95 (Masculine).

Persepsi atas korupsi yang menjadi variabel moderasi secara umum disebut dengan tindakan yang disengaja untuk penyalahgunaan kekuasaan yang dipercayakan menguntungkan diri sendiri. Persepsi atas korupsi dikelompokkan sebagai korupsi besar, korupsi kecil, dan juga korupsi politis, tergantung jumlah uang yang hilang dan sektor tempat terjadinya. Selain itu korupsi juga dapat diartikan sebagai suatu bentuk 
kejahatan yang tergolong sebagai kejahatan yang terorganisir (Huisman \& Walle, 2010). Variabel ini diukur dengan menggunakan data dari Corruption Perception Indeks oleh Transparency International (https://www.transparency.org/country) jika 0-19 (Sangat Korup), 20-39 (Cenderung Korup), 40-59 (Rentan Korup), 60-79 Cenderung bersih, 80-100 (Sangat bersih).

Agresivitas pajak sebagai variabel dependent diukur dengan menggunakan pertanyaan dalam WBES "Dalam tahun terakhir, perusahaan diperiksa oleh petugas pajak berapa kali atau dari pihak perusahaan harus bertemu dengan petugas pajak?". Pengukuran yang didapat itu melalui WBES dan diukur melalui tiga kategori yaitu yang pertama adalah tidak terjadi agresivitas pajak jika pada tahun pengamatan tidak ada pemeriksaan oleh petugas pajak; kategori kedua yaitu agresivitas pajak sebagian jika perusahaan diperiksa oleh petugas pajak kurang dari 30 hari, kategori ketiga agresivitas pajak penuh jika perusahaan diperiksa petugas pajak lebih dari 30 hari

Studi ini menggunakan dua variabel kontrol yaitu ukuran perusahaan dan umur perusahaan. Ukuran perusahaan merupakan ukuran besar kecilnya suatu perusahaan. Rindawati dan Asyik (2014) menyatakan bahwa ukuran perusahaan merupakan salah satu variabel yang dapat digunakan untuk pengungkapan suatu informasi perusahaan. Semakin besar suatu ukuran perusahaan maka akan semakin luas dan banyak pemangku kepentingannya. Variabel ukuran perusahaan diukur dengan empat kategori yaitu perusahaan mikro dengan jumlah karyawan kurang dari 5, yang kedua yaitu perusahaan kecil dengan jumlah karyawan 6-19 karyawan, yang ketiga yaitu perusahaan menengah dengan total karyawan 20-99 karyawan dan yang keempat yaitu perusahaan besar dengan lebih dari 100 karyawan. Sementara umur perusahaan yang didefinisikan sebagai lamanya perusahaan tersebut beroperasi diukur dengan menggunakan pertanyaan dari WBES "Pada tahun berapa mulai beroperasi di negara tersebut?". Jawaban responden akan berupa tahun berdirinya perusahaan di negara tersebut, sehingga diperoleh umur perusahaan dengan mengurangi tahun data yang diperoleh dengan tahun perusahaan itu berdiri.

Dalam menguji hipotesis pada penelitian ini yang digunakan yaitu uji Multinomial Logistic Regression (MLR). Untuk melihat apakah budaya nasional berpengaruh terhadap penggelapan pajak sekaligus dengan variabel lainnya yaitu persepsi atas korupsi sebagai variabel moderasi dan ukuran perusahaan, karakteristik perusahaan, dan politik sebagai variabel kontrol. Multinomial Logistic Regression merupakan perkembangan dari dua kategori, dalam penelitian ini variabel dependen memiliki lebih dari dua kategori. Variabel dependent penggelapan pajak memiliki tiga kategori diantaranya, tidak ada penggelapan pajak, penggelapan pajak sebagian dan penggelapan pajak penuh. 


\section{Hasil dan Pembahasan}

Berdasarkan hasil tabel statistik deskriptif perusahaan formal berdasarkan data WBES dengan jumlah 44.527 pada 142 negara, agresivitas pajak memiliki nilai ratarata sebesar 2,01. Data tersebut diperoleh dari responden yang melakukan agresivitas pajak dengan kategori persentase terbanyak yaitu dari agresivitas pajak sebagian sebesar 99,4\%. Persepsi atas korupsi merupakan data yang diperoleh dari Indeks Persepsi Korupsi dari berbagai negara memiliki nilai rata-rata sebesar 2,26 yang ditunjukkan poin persentase terbesar yaitu negara yang cenderung melakukan korupsi dengan presentasi 76,1\%, dari presentasi tersebut berarti setiap perusahaan di berbagai negara cenderung melakukan korupsi dalam hal melakukan kecurangan membayar perpajakannya. Jarak kekuasaan pada suatu perusahaan memiliki nilai rata-rata sebesar 1,92 dengan persentase sebesar 92\%, Individualisme pada suatu negara memiliki nilai rata-rata sebesar 1,06 dengan persentase sebesar 93,7\% pada kategori collectivism, Ketidakpastian atas peraturan perpajakan memiliki nilai ratarata sebesar 1,57 dengan persentase sebesar 57\%, dan Maskulinitas memiliki nilai rata-rata sebesar 1,41 dengan persentase terbesar pada kategori Feminism sebesar $58,8 \%$.

\section{Tabel 1. Statistik Deskriptif}

\begin{tabular}{|c|c|c|c|c|}
\hline \multicolumn{2}{|c|}{ Variabel } & $\%$ & Mean & Std. Dev \\
\hline \multirow{3}{*}{ Agresivitas Pajak } & Tidak ada agresivitas & 0,0 & \multirow{3}{*}{2,01} & \multirow{3}{*}{0,078} \\
\hline & agresivitas sebagian & 99,4 & & \\
\hline & agresivitas pajak penuh & 0,6 & & \\
\hline \multirow{4}{*}{ Persepsi atas Korupsi } & Sangat korup & 2,2 & \multirow{4}{*}{2,26} & \multirow{4}{*}{0,593} \\
\hline & Cenderung korup & 76,1 & & \\
\hline & Rentan Korup & 15,8 & & \\
\hline & Cenderung Bersih & 5,9 & & \\
\hline \multirow{2}{*}{ Jarak Kekuasaan } & Small & 8,0 & \multirow{2}{*}{1,92} & \multirow{2}{*}{0,271} \\
\hline & Large & 92,0 & & \\
\hline \multirow{2}{*}{ Individualisme } & Collectivism & 93,7 & \multirow{2}{*}{1,06} & \multirow{2}{*}{0,243} \\
\hline & Individualism & 6,3 & & \\
\hline \multirow{2}{*}{ Ketidakpastian } & Weak & 43,0 & \multirow{2}{*}{1,57} & \multirow{2}{*}{0,495} \\
\hline & Strong & 57,0 & & \\
\hline \multirow{2}{*}{ Maskulinitas } & Feminism & 58,8 & \multirow{2}{*}{1,41} & \multirow{2}{*}{0,492} \\
\hline & Masculine & 41,2 & & \\
\hline
\end{tabular}

Sumber: Olah data SPSS 2020

Hasil pengujian hipotesis menggunakan multinomial logistic regression ditunjukkan pada Tabel 2 yang menunjukkan bahwa nilai Pseudo $\mathrm{R}^{2}$ adalah sebesar 0,049 yang berarti variabel independent individualisme, jarak kekuasaan, ketidakpastian dan maskulinitas berpengaruh terhadap variabel dependen yaitu agresivitas pajak sebesar 4,9\%. Sisanya 95,1\% berasal dari variabel lain yang tidak terdapat dalam model.

Uji parsial digunakan untuk melihat pengaruh dari masing-masing variabel independen yaitu budaya nasional, terhadap variabel dependen yaitu agresivitas pajak dan juga untuk melihat pengaruh dari variabel yang memoderasi variabel independen yaitu persepsi atas korupsi terhadap agresivitas pajak. 
Dari hasil uji parsial, dapat diketahui independent yaitu jarak kekuasaan, individualisme, ketidakpastian tidak memiliki pengaruh terhadap agresivitas pajak. Hal tersebut ditandai dengan nilai sig jarak kekuasaan 0,167, individualisme 0,645 ketidakpastian 0,212, persepsi atas korupsi 0,424 yang diatas 0,05. Namun variabel maskulinitas memiliki nilai 0,001 memiliki pengaruh terhadap agresivitas pajak yang ditandai oleh nilai Sig dibawah 0,05. Namun variabel kontrol yaitu ukuran perusahaan dan umur perusahaan dapat mengendalikan variabel independent sehingga variabel kontrol memiliki pengaruh dalam mengendalikan variabel independen untuk memberikan pengaruh terhadap agresivitas pajak tersebut.

\section{Tabel 2. Pengujian Hipotesis}

\begin{tabular}{|c|c|c|c|}
\hline \multicolumn{4}{|c|}{ Panel A.Pengujian Multinomial Logistic Regression } \\
\hline Variabel & $\chi^{2}$ & Sig. & Keterangan \\
\hline Jarak Kekuasaan & $1.457,167$ & $0,167^{*}$ & Ditolak \\
\hline Individualisme & $1.454,460$ & $0,645^{*}$ & Ditolak \\
\hline Ketidakpastian & $1.456,684$ & $0,212^{*}$ & Ditolak \\
\hline Maskulinitas & $1.466,753$ & $0,001^{* *}$ & Diterima \\
\hline \multicolumn{4}{|c|}{ Panel B. Pengujian Moderasi } \\
\hline $\begin{array}{c}\text { Persepsi atas Korupsi x Jarak } \\
\text { Kekuasaan }\end{array}$ & $1.456,049$ & $0,292^{*}$ & Ditolak \\
\hline Persepsi atas Korupsi x Individualisme & $1.454,490$ & $0,636^{*}$ & Ditolak \\
\hline Persepsi atas Korupsi x Ketidakpastian & $1.455,919$ & $0,311^{*}$ & Ditolak \\
\hline Persepsi atas Korupsi x Maskulinitas & $1.464,589$ & $0,004^{* *}$ & Diterima \\
\hline \multicolumn{4}{|c|}{ Variabel Kontrol } \\
\hline Umur Perusahaan & $1.460,236$ & 0,036 & \\
\hline Ukuran Perusahaan & $1.509,791$ & 0,000 & \\
\hline
\end{tabular}

Variabel dependen: agresivitas pajak; Pseudo $\mathrm{R}^{2}=0,049$; ${ }^{*}$-value (sig.) $>0,05$ = tidak berpengaruh terhadap agresivitas pajak; ${ }^{* *}$ p-value $(\mathrm{sig})<0,05=$ berpengaruh terhadap agresivitas pajak.

Sumber: Olah data SPSS 2020

Dari hasil Tabel 2 menunjukkan bahwa jarak kekuasaan tidak berpengaruh terhadap agresivitas pajak. Hasil ini tidak mendukung dengan penelitian Richardson (2008) dan Tsakumis et al., (2007) yang mengatakan bahwa negara yang memiliki jarak kekuasaan berpengaruh terhadap agresivitas pajak. Namun pada penelitian ini menunjukkan bahwa negara yang memiliki jarak kekuasaan yang tinggi tidak mempengaruhi negara tersebut untuk melakukan agresivitas pajak. Hal ini disebabkan meskipun negara yang memiliki jarak kekuasaan seperti ketidaksetaraan kekuasaan dan kekayaan yang tinggi dalam sistem pemungutan pajak tetap adil sehingga tidak ada yang dirugikan kepada seseorang untuk melakukan tindakan agresivitas pajak. Dari hasil Tabel 2 menunjukkan bahwa individualisme tidak terhadap agresivitas pajak. Hal ini disebabkan negara individualisme masyarakatnya memiliki tujuan untuk tetap fokus pada pencapaian secara individu ataupun secara kolektif. Pada negara yang memiliki nilai individualisme yang tinggi, standar aturan yang berlaku pada setiap orang sama. Maka dari itu sistem pemungutan pajak cenderung merata karena dalam peraturan undang-undang pajak berlaku bagi setiap orang dengan cara yang sama, sehingga masyarakat yang individualisme ini tidak melakukan tindakan agresivitas pajak. 
Ketidakpastian pada Tabel 2 menunjukkan tidak berpengaruh terhadap agresivitas pajak. Hasil ini tidak mendukung Richardson (2008) yang menunjukkan bahwa pada tingkat penghindaran ketidakpastian yang lebih tinggi maka tingkat agresivitas pajak lebih tinggi di berbagai negara. Hal ini disebabkan karena seperti contoh dalam pemungutan pajak penghasilan biasanya orang yang memberi penghasilan yang langsung memotong kewajiban perpajakannya sehingga mereka tidak merasakan kesulitan pengurusan pajak. Maskulinitas pada Tabel 4 menunjukkan positif terhadap agresivitas pajak. Hal ini disebabkan masyarakat maskulin memiliki keinginan bahwa kesuksesannya dilihat seluruh masyarakat serta ingin memiliki kesejahteraan yang menyebabkan agresivitas pajak.

Hasil yang diperoleh pada Tabel 2 menunjukkan bahwa jarak kekuasaan dengan moderasi persepsi atas korupsi tidak berpengaruh terhadap agresivitas pajak. Walaupun dengan adanya persepsi atas korupsi, tidak mempengaruhi perusahaan dengan jarak kekuasaan tinggi atau rendah untuk melakukan agresivitas pajak. Jarak kekuasaan pada suatu negara menunjukkan adanya perbedaan jabatan antara atasan dan bawahan. Jika jarak kekuasaan pada negara tersebut tinggi, maka perusahaan akan lebih memiliki rasa bertanggung jawab Hofstede (1980) dan jika jarak kekuasaan pada negara tersebut rendah, maka perusahaan akan lebih bertindak dengan hati-hati. Persepsi atas korupsi tindakan yang akan menimbulkan risiko di masa mendatang dan orang yang melakukan tindakan korupsi tidak memiliki rasa tanggung jawab karena tujuannya adalah memperkaya diri sendiri dan merugikan orang lain (Meidya Rachmania et al., 2016). Sehingga persepsi atas korupsi tidak dapat mempengaruhi perusahaan dengan jarak kekuasaan yang tinggi maupun rendah untuk melakukan tindakan agresivitas pajak.

Pada Tabel 2 hasil pengujian hipotesis menunjukkan bahwa budaya nasional individualisme dengan persepsi atas korupsi sebagai moderasi tidak berpengaruh terhadap agresivitas pajak. Negara dengan tingkat individualisme tinggi, cenderung tidak akan terjadi agresivitas pajak walaupun terdapat korupsi. Pejabat di negara dengan tingkat individualisme tinggi memiliki pola pikir yang lebih bijaksana dan akan lebih berhati-hati dalam bertindak (Pillay \& Dorasamy, 2010). Pola pikir yang bijaksana ini dapat menghilangkan minat seseorang untuk melakukan tindakan korupsi maupun tindakan agresivitas pajak. Menurut Basri (2016) negara dengan tingkat individualisme tinggi memiliki sistem pajak dan prosedur yang diterapkan pada negara tersebut sama rata untuk seluruh masyarakat. Meratanya sistem dan prosedur pajak yang diberlakukan pada seluruh masyarakat, membuat perusahaan lebih patuh terhadap pajak karena tidak ada yang diringankan maupun diberatkan dari sistem dan prosedur pajak tersebut.

Hasil pengujian hipotesis menunjukkan bahwa ketidakpastian dengan variabel moderasi persepsi atas korupsi tidak berpengaruh terhadap agresivitas pajak. Hal ini bisa saja terjadi karena peraturan pajak pada setiap negara yang berbeda, dan sebagian besar perusahaan beranggapan bahwa peraturan pajak di negara tersebut tidak rumit. Semakin rumit peraturan semakin tinggi tingkat kecurangan pajak akan 
terjadi dan sebaliknya (Basri, 2016). Negara dengan tingkat ketidakpastian yang tinggi menunjukkan bahwa negara tersebut akan cenderung menghindari risiko (Kusmanto, 2010), sedangkan dengan melakukan persepsi atas korupsi akan meningkatkan tingkat risiko yang akan diterima dimasa yang akan datang. Persepsi korupsi yang tinggi ataupun rendah tidak akan mempengaruhi perusahaan untuk melakukan atau tidak melakukan agresivitas pajak. Sehingga walaupun persepsi korupsi pada negara tersebut tinggi, tidak akan mempengaruhi perusahaan tersebut untuk melakukan tindakan pajak, melainkan yang mendorong perusahaan untuk melakukan agresivitas pajak adalah tingkat kerumitan dalam mengurus pajak di suatu negara.

Maskulinitas dengan variabel moderasi pada Tabel 2 menunjukkan hasil positif terhadap agresivitas pajak. Hal ini terjadi karena masyarakat dengan maskulinitas tinggi cenderung masyarakatnya ingin meningkatkan ego, kekayaan dan kesejahteraan diri sendiri agar dapat dilihat seluruh masyarakat serta ingin memiliki kesejahteraan dalam hidupnya sehingga masyarakatnya melakukan tindakan persepsi atas korupsi dan melakukan agresivitas pajak agar dapat memenuhi semua pencapaiannya.

\section{Simpulan}

Berdasarkan hasil analisis yang dilakukan, dapat diambil kesimpulan bahwa terdapat tiga dimensi dalam budaya nasional yang tidak berpengaruh terhadap agresivitas pajak. Hal tersebut ditunjukkan meskipun di suatu negara yang memiliki jarak kekuasaan yang tinggi, namun tidak mempengaruhi agresivitas pajak tersebut akan rendah. Individualisme pada suatu negara tidak mempengaruhi sikap mereka untuk melakukan tindakan agresivitas pajak. Selain itu ketidakpastian dalam suatu peraturan perpajakan juga tidak berpengaruh terhadap seseorang atau perusahaan untuk melakukan agresivitas pajak. Namun dimensi lain dalam penelitian ini yang memiliki pengaruh positif terhadap agresivitas pajak yaitu maskulinitas. Hasil penelitian ini mendukung Tsakumis dan Doupnik (2004) menunjukkan masyarakat maskulin memiliki keinginan kesuksesannya dilihat oleh seluruh masyarakat sehingga seseorang melakukan agresivitas pajak.

Penelitian ini membuktikan bahwa persepsi atas korupsi sebagai variabel moderasi tidak dapat memperkuat hubungan antara jarak kekuasaan, individualisme dan ketidakpastian dengan agresivitas pajak. Namun berbeda dengan dimensi maskulinitas, variabel moderasi persepsi atas korupsi mampu memperkuat hubungan dengan agresivitas pajak. Hal tersebut ditunjukkan karena masyarakat yang maskulinitas tinggi cenderung melakukan korupsi untuk meningkatkan ego, kekayaan dan kesejahteraan diri sendiri, sehingga masyarakat tersebut melakukan agresivitas pajak agar dapat memenuhi kepuasan diri sendiri.

Keterbatasan dalam penelitian ini yaitu dalam variabel independen yang dapat mempengaruhi agresivitas pajak, sehingga ada variabel lain yang dapat mempengaruhi agresivitas pajak. Saran untuk penelitian selanjutnya dapat 
menambah dimensi lainnya dalam melihat budaya nasional terhadap agresivitas pajak. Selain dari itu bisa menggunakan perusahaan lainnya selain perusahaan formal.

\section{Daftar Pustaka}

Andreoni, J., Erard, B., \& Feinstein, J. (1998). Tax Compliance. Jurnal of Economic Literature, 36, 818-860.

Asmoro, L. A. (2016). Perang Tarif Pajak Menarik Investasi. https://www.pajak.go.id/id/artikel/perang-tarif-pajak-menarik-investasi

Bame-Aldred, C. W., Cullen, J. B., Martin, K. D., \& Parboteeah, K. P. (2013). National culture and firm-level tax evasion. Journal of Business Research, 66(3), 390-396. https://doi.org/10.1016/j.jbusres.2011.08.020

Basri, Y. M. (2016). Pengaruh Dimensi Budaya Dan Religiusitas Terhadap Kecurangan Pajak. Akuntabilitas, 8(1), 61-77. https://doi.org/10.15408/akt.v8i1.2764

Brock, G., \& Pogge, T. (2014). Global tax justice and global justice. Moral Philosophy and Politics, 1(1), 1-15. https://doi.org/10.1515/mopp-2014-0999

Christianto, V. F., \& Suyanto. (2014). Pengaruh Pemahaman Tindak Pidana Korupsi Dan Pemahaman Penghindaran Pajak Terhadap Tingkat Kepatuhan Wajib Pajak Dalam Pembayaran Pajak Di Daerah Istimewa Yogyakarta. Vol 13(No 1), Hal 35-52.

Fochmann, M., \& Kroll, E. B. (2016). The effects of rewards on tax compliance decisions. Journal of Economic Psychology, 52(September), 38-55. https://doi.org/10.1016/j.joep.2015.09.009

Giles, D. E. A. (1998). The Underground Economy: Minimizing the Size of Government. 3-18. https://www.uvic.ca/socialsciences/economics/assets/docs/discussion/ottawa.pdf

Hofstede, G. (1980). Culture and Organizations AU - Hofstede, Geert. International Studies of Management \& Organization, 10(4), 15-41. https://doi.org/10.1080/00208825.1980.11656300

Hofstede, G. (2001). Culture's Recent Consequences: Using Dimension Scores in Theory and Research. 1(1), 2-7.

Hofstede, Geert. (2011). Dimensionalizing Cultures: The Hofstede Model in Context. Online Readings in Psychology and Culture, 2(1), 1-26. https://doi.org/10.9707/23070919.1014

Huisman, W., \& Walle, G. Vande. (2010). The criminology of corruption. ... Theoretical Perspectives on Corruption 1-.., http://pure.hogent.be/portal/files/6109339/9th_chapter_Criminology_of_Corrupti on.pdf

IRS. (2007). Reducing the Federal Tax Gap - A Report on Improving Voluntary Compliance. http://www.irs.gov/pub/irsnews/tax_gap_report_final_080207_linked.pdf

Khlif, H., \& Amara, I. (2017). About Emerald www.emeraldinsight.com Financial crime , corruption and tax evasion: A cross-country investigation. 
Kusmanto, F. (2010). Budaya Nasional terhadap Korupsi. Kompasiana, Politik.

Long, S., Swingen, J., Roth, J., Scholz, J., \& Witte, A. D. (1991). Taxpayer Compliance: Setting New Agendas for Research. Law \& Society Review, 25(3), 637. https://doi.org/10.2307/3053731

Mardiasmo. (2009). Perpajakan Edisi Revisi (Revisi). Andi.

Meidya Rachmania, F., Siti Astuti, E., \& Nayati Utami, H. (2016). Pengaruh Persepsi Korupsi Pajak dan Kualitas Pelayanan Fiskus Terhadap Kepatuhan Wajib Pajak (Studi pada Wajib Pajak Orang Pribadi yang Terdaftar di KPP Pratama Batu). Jurnal Perpajakan (JEJAK), 10(1), 1-8.

Nielsen, S. B., Raimondos-Møller, P., \& Schjelderup, G. (2010). Company taxation and tax spillovers: Separate accounting versus formula apportionment. European Economic Review, 54(1), 121-132. https://doi.org/10.1016/j.euroecorev.2009.06.005

Picur, R. D., \& Riahi-Belkaoui, A. (2006). The impact of bureaucracy, corruption and tax compliance. Review of Accounting and Finance, 5(2), 174-180. https://doi.org/10.1108/14757700610668985

Pillay, S., \& Dorasamy, N. (2010). Linking cultural dimensions with the nature of corruption: An institutional theory perspective. International Journal of Cross Cultural Management, 10(3), 363-378. https://doi.org/10.1177/1470595810389793

Rahayu, S. K. (2010). Perpajakan Indonesia Edisi Pertama. Yogyakarta : Graha Ilmu.

Richardson, G. (2006). Determinants of tax evasion: A cross-country investigation. Journal of International Accounting, Auditing and Taxation, 15(2), 150-169. https://doi.org/10.1016/j.intaccaudtax.2006.08.005

Richardson, G. (2008). The relationship between culture and tax evasion across countries: Additional evidence and extensions. Journal of International Accounting, Auditing and Taxation, 17(2), 67-78. https://doi.org/10.1016/j.intaccaudtax.2008.07.002

Rindawati, \& Asyik. (n.d.). Pengaruh Profitabilitas, Ukuran perusahaan, Leverage, dan Kepemilikan Publik terhadap Pengungkapan Corporate Social Responsibility (CSR). 2014.

Transparency, I. (2018). What Is Corruption. https://www.transparency.org/what-iscorruption

Tsakumis, G. T., Curatola, A. P., \& Porcano, T. M. (2007). The relation between national cultural dimensions and tax evasion. Journal of International Accounting, Auditing and Taxation, 16(2), 131-147. https://doi.org/10.1016/j.intaccaudtax.2007.06.004

Tsakumis, G. T., \& Doupnik, T. S. (2004). A CRITICAL REVIEW OF TESTS OF GRAY'S THEORY OF CULTURAL RELEVANCE AND SUGGESTIONS FOR FUTURE RESEARCH.

Veithzal, R. (2013). Kepemimpinan dan Perilaku Organisasi. Jakarta: PT. Raja Grafindo, 236. 